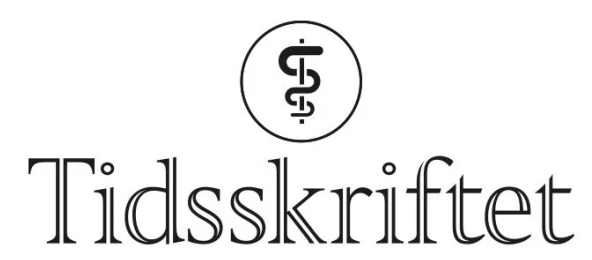

DEN NORSKE LEGEFORENING

\title{
Re: Ruset i ord
}

\author{
BREV TIL REDAKTØREN
}

\section{ØYVIND WATNE}

Øyvind Watne (f. 1951) er overlege ved Tiller DPS, St. Olavs hospital. Ingen oppgitte interessekonflikter Email: oyvind.watne@stolav.no

I Tidsskriftet nr. 5/2014 drøfter Hem om ein skal nytte nemninga rusmisbrukar eller rusmiddelmisbrukar (1). Eg vil argumentere for å skrote bruken av begge orda.

Orddelen «mis» har etter mitt skjøn eit moralistisk element. Bruken av ordet peiker mot at noko er gjort feil eller gale, jamfør misdåd eller mistyding. ICD har meir nøytrale, deskriptive nemningar for å kategorisere lidingar relaterte til rusbruk, til dømes skadeleg bruk (F1X.1) eller avhengnad (F1X.2).

Eg oppfattar at det å karakterisere pasientar utelukkande med lidinga si er på veg ut. Det er ikkje berre utviklinga i dagkirurgi som gjer at ein ikkje lenger snakker som «brokket i 3 senga på 213". Lat oss også innafor medisin elles snakke om "pasient med rusliding», eller

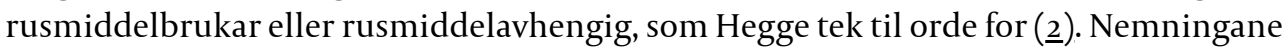
Hem drøfter bruken av, treng vi ikkje i fagleg samanhang.

\section{LITTERATUR}

1. Hem E. Ruset i ord. Tidsskr Nor Legeforen 2014; 134: 537. [PubMed]

2. Hegge PE. Språket vårt: Alle livene deres. Aftenposten 11.8.2013: 4. http://tux.aftenposten.no/spraak/spraak?action=question\&id=5099(14.3.2013).

Publisert: 29. april 2014. Tidsskr Nor Legeforen. DOI: 10.4045/tidsskr.14.0455

(C) Tidsskrift for Den norske legeforening 2023. Lastet ned fra tidsskriftet.no 26. april 2023. 